\title{
Effect of Cold Stress on Nursery Argan (Argania spinosa (L.) Skeels) Seedlings Production
}

\author{
M. Alouani ${ }^{1}$, F. Bani-Aameur ${ }^{2}$ \\ ${ }^{1}$ Ecole Supérieure de Technologie Laayoune, Laboratoire de Biotechnologie et de Valorisation des Ressources \\ Naturelles, Université Ibn Zohr, Agadir (Morocco) \\ ${ }^{2}$ Faculté des Science Agadir, Laboratoire de Biotechnologie et de Valorisation des Ressources Naturelles, \\ Université Ibn Zohr, Agadir (Morocco)
}

\begin{abstract}
Effect of the cold period was investigated as a limiting factor for nursery argan (Argania spinosa (L.) Skeels) seedlings production. The effect of the cold period (from November to January was characterized by minimum temperatures $\leq 10^{\circ} \mathrm{C}$ ) on the survival of argan seedlings elevated in the seedling trays was studied during two years. In the first year, seedlings of 15 different mother-trees were elevated in the open air (without shade house), while seedlings of 30 genotypes of the second year were growing under shade house. Effect of the cold period of the seedlings without shade house was characterized by yellowing and drying of leaves. Cold stress affects $47.9 \%$ of seedlings while 53.9\% of these seedlings recovered by the appearance of new leaves. The reaction of mother-trees to cold stress is significantly variable, and the percentage loss of seedlings under the influence of cold, after the resumption of seedlings ranged from 6.9\% for mother-tree 3 and 35.9\% for mothertree 9. By contrast, no loss is recorded during the cold period for seedlings grown under shade house.
\end{abstract}

Keywords: Argania spinosa, shade house, cold stress period, seedlings production, mother-tree reaction.

\section{Introduction}

Argan (Argania spinosa (L.) Skeels) is an endemic tree of arid territories in Morocco [1] [2], surviving to drought periods and able to produce leaves, branches and fruits with as little as $100 \mathrm{~mm}$ rainfall [3], [4], [5], [6]. The natural limits of the argan trees are given mainly by climate [1] and they are located at the lowest snowline. Argan trees can resist to temperatures below $0{ }^{\circ} \mathrm{C}$ only a short time [7]. Argan, mainly used for the edible oil extracted from its fruit, and has recently received increased attention as a candidate for domestication and as a non-timber producing tree for environment preservation and rural communities well being. However, in the continental arid like the pre-Saharan areas, the cold remains the major obstacle to the extension of argan and several other species [8]. Argan is a menaced species because of over-use and the lack of neither natural nor artificial regeneration [9] [10] [11] [12] [13].

Germination and early seedling development stages are critical periods for the establishment of plant species [14]. However, argan seed germination was improved by combining scarification, chilling, gibberellic acid and fungicide treatments [15] [16] and light treatment [17]. Among various environmental stresses, low temperature is one of the most important factors limiting the productivity and geographical distribution of plants across the world [18] [19]. Low temperatures, defined as low but not freezing temperatures $\left(0-15^{\circ} \mathrm{C}\right)$, are common in nature and can damage many plant species, while several plant species have the ability to increase their tolerance in response to low temperatures [19] [20] [21] [22] [23]. The roots and leaves are more susceptible to cold conditions [24] [25] [26] [27] [28]. Nursery argan seedlings production is very low due to the low percentage of seed germination and attack seedling aged less than five months by Fusarium [6] [29]. The effect of cold stress (minimum temperature during the cold period is $\leq 10^{\circ} \mathrm{C}$ ) on the survival of argan seedlings in nursery was identified by preliminary observations [29], but it is not yet studied. It has been reported that when seedlings of argan aged one year and a half and those aged six to eight months, from 90 mother-tree genotypes were transplanted in the experimental station of the Regional Directorate of Water and Forests Tanssift Sidi Jaber Elkalaa (arid and cold region), all the seedlings died after a week of freezing $\left(-2^{\circ} \mathrm{C}\right)$.

Lamhamedi and al. [30] found that the use of shades house in nurseries in arid and semi-arid areas is important against the exposure and sensitivity of seedlings to thermal stress. However, the use of shade house is not widespread in all nurseries. Currently, the production of argan seedlings in the nursery is in the open air without any protection. Effect of cold stress on survival of argan seedling produced in the open air (without shade house) or under shade house need more investigations. Our goal in this study is to compare on the one hand, the reaction of argan seedlings, from different mother-trees (genotypes) during cold period and shows secondly the importance of the shade house on surviving seedlings during this period.

\section{Materials And Methods}

Effects of cold periods on seedlings growth were studied in field conditions during two consecutive years by two tests (I and II). Ripe argan fruits were collected from 15 and 30 argan mother trees (genotypes) 
respectively for test I and test II. The experiments were carried out in Agadir (located in south of Morocco), during June of each year when the minimum temperature exceeds $10{ }^{\circ} \mathrm{C}$. Indeed, this temperature condition was considered favorable for seedling growth [31].

\subsection{Argan seedlings}

The protocol for pre-treatment of argan seeds was developed by Alouani and Bani-Aameur [15]. Since, the fruits from each mother-tree (genotype) were hulled and the stones were maintained at $4{ }^{\circ} \mathrm{C}$. The stones were soaked in $2 \%$ chlorine solution for 15 minutes and then washed by distilled water. They were then scarified by slightly cracking them and immediately treated with the fungicide (Thirame). Thereafter, the stones were soaked for 24 hours in a gibberellic acid solution (GA3) at $1000 \mathrm{ppm}$ and then rinsed twice with fresh water. The stones of each genotype were germinated in a plastic tray $(40 \times 30 \times 10 \mathrm{~cm} 3)$ filled with sterile sand and the optimum moisture was maintained by application of distilled water. The plastic trays were placed under mini-greenhouses covered with clear plastic and stones were exposed to direct natural daylight [17]. Seedlings from the germination test of these stones were planted in seedling trays filled with a substrate consisting of peat moss, sand and argan forest soil (1:1:1). The soil moisture was maintained constant by application of water every 48 hours

\subsection{Effects of cold periods on seedlings argan}

In the first test, seedlings were placed in the open air (without shade house), while those of the second test were placed under shade (with shade house). The number of surviving seedlings (NSS) was recorded for each trial four dates of observations (July, August, November and February). At the end of January, we calculated the average percentage of seedlings affected by cold (SAC) (yellowing and drying of part or all of the leaves), the percentage of recovery seedlings in relation to the number of seedlings affected by cold stress (RS/SAC) and the percentage of lost seedlings (seedlings remained dry) under the effect of cold stress after the resumption of seedlings (SRDC). We noted here that the absence of contaminants was checked in dead plants on middle acidified PDA.

\subsection{Statistical analysis}

Different mother-trees of plants were distributed in an experimental randomized complete block factorial design. For seedling survival, the factors: block, date of observation and mother-tree (15 for test 1 and 30 for test 2) were crossed [32] [33]. The experimental design consists of a seedling tray where 40 germinated seeds were planted. For the percentage of loss and recovery seedlings (SAC, RP / SAC and SRDC), the factors: block and mother-trees were crossed and a square root transformation $(\mathrm{x}+0.5)$ was performed on percentages for statistical analysis. The Least Significant Difference (LSD) test $(\alpha=5 \%)$ of equality of means was used to compare significant factors means. Statistical analysis was performed by Statistix software

\section{Results}

Factors mother-tree and date of observation were highly significant for surviving seedlings for the two tests; however, their interaction was only significant for surviving seedlings placed without shade house (Table 1). Mean percentage of surviving seedlings was very variable depending on the date of observation (Fig. 1). When the seedlings are not covered with shade, it was $78.0 \%$ after about two months of aging, $65.7 \%$ after five months and it was only $51.0 \%$ after seven months. This shows that even after five months (November to February), the percentage of seedling survival was not yet stabilized. We noted here that the average percentage of seedling survival under shade house was $78.0 \%$ after about two months of aging and it was stabilized after five months to $77.2 \%$. Loss of seedlings under shade house during the cold period, November to February, was null.

Table1. Analysis of variance of the number of surviving seedlings in the two tests (with and without shade house).

\begin{tabular}{|l|l|l|l|}
\hline & Sources of variation & Degrees of freedom & Mean square \\
\hline Without shade house & & & \\
\hline \multirow{5}{*}{} & Block & 1 & $3.68 \mathrm{~ns}$ \\
\cline { 2 - 4 } & Date of observation (DO) & 3 & $1261.20 * *$ \\
\cline { 2 - 4 } & Mother - tree (MT) & 14 & $175.59 * *$ \\
\cline { 2 - 4 } & DO x MT & 42 & $7.83 * *$ \\
\cline { 2 - 4 } & Error & 59 & 2.08 \\
\hline \multirow{5}{*}{ With shade house } & & 1 & $0.94 \mathrm{~ns}$ \\
\hline \multirow{5}{*}{} & Block & 3 & $6.74 * *$ \\
\cline { 2 - 4 } & Date of observation (DO) & 29 & $2.24 * *$ \\
\cline { 2 - 4 } & Mother - tree (MT) & 87 & $0.21 \mathrm{~ns}$ \\
\cline { 2 - 4 } & DO x MT & 119 & 2.12 \\
\cline { 2 - 4 } & Error & & \\
\hline
\end{tabular}

ns: non significant, $* *$ : significant at 0.01 


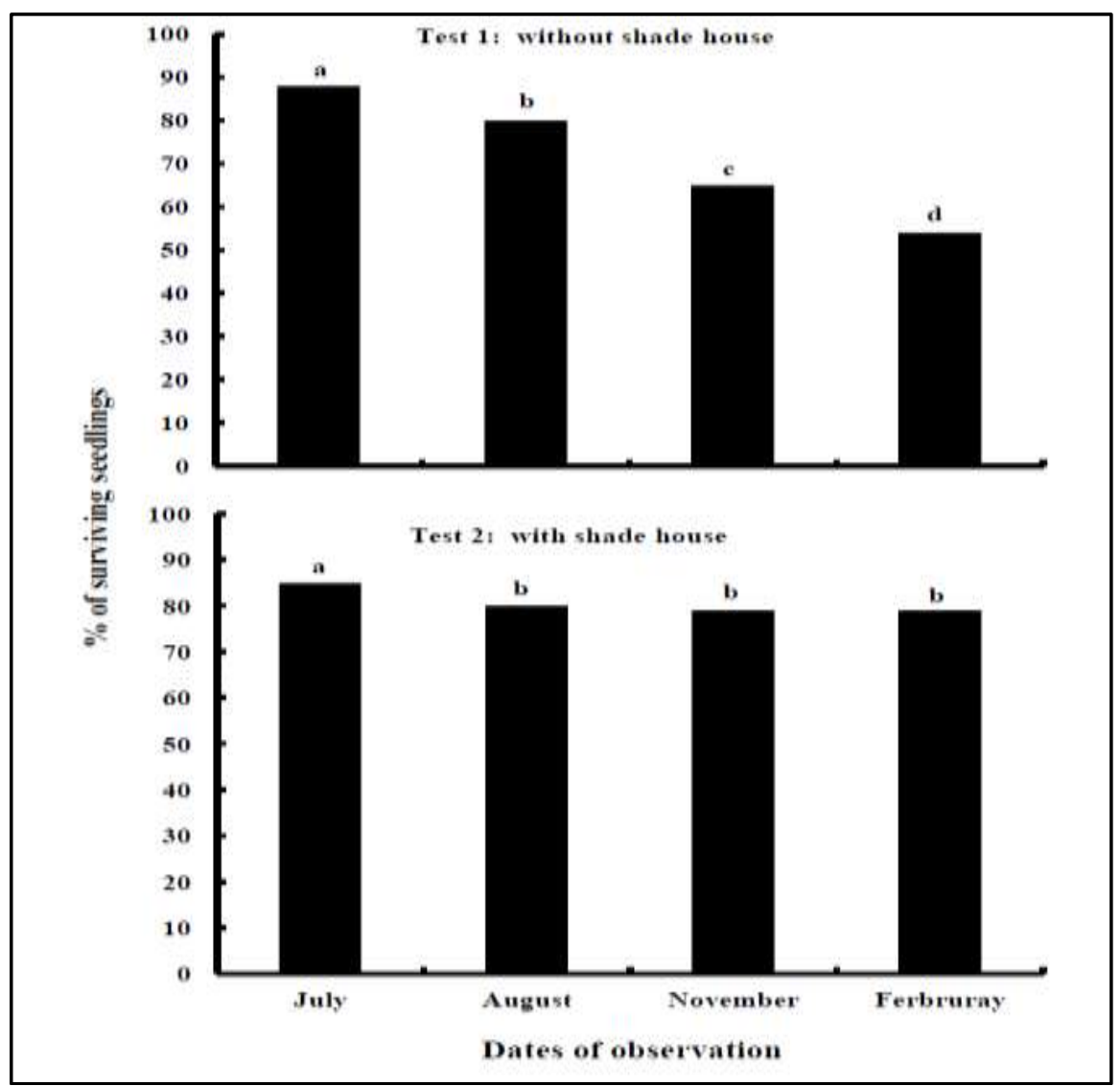

Figure 1. Percentage of surviving seedlings according to the observation date for two tests (with and without shade house). Different letters note significant differences (LSD at 0.05 level)

When the seedlings were not covered with shade house, the mean surviving seedlings percentage varied between $49.4 \%$ and $93.3 \%$ depending on mother-tree (Table 2). On the other hand, this percentage was varied between $68.8 \%$ and $92.5 \%$ for seedlings under shade house. In seedlings without shade house, the reaction of seedlings under the influence of the cold period (November to January, a period characterized by minimum temperatures $\leq 10^{\circ} \mathrm{C}$ (Fig. 2)), is manifested by yellowing and leaf scorch (SAC). Some of these seedlings start their activity by the appearance of new leaves (RP/SAC), while others were lost (SRDC).

Table 2. Minimum, maximum and average seedling surviving in both trials.

\begin{tabular}{|l|l|l|}
\hline & Percentage of seedlings surviving \\
\hline & without shade house & with shade house \\
\hline Minimum & 49.4 & 68.8 \\
\hline Maximum & 93.3 & 92.5 \\
\hline Average & 70.86 & 79.21 \\
\hline
\end{tabular}

Mother-tree factor was highly significant on the average percentage of seedlings with symptoms (SAC) (Table 3). We observed no significant effect on the percentage of recovery of seedlings compared to the number of seedlings with symptoms (RP/SAC) or the percentage of seedlings lost under cold effect after the resumption of seedlings (SRDC).

Table3. Analysis of variance of the mean percentage of seedlings affected by cold stress (SAC), resumption of seedlings from the seedling numbers affected by cold stress (RS / SAC) and seedlings lost as a result of cold

\begin{tabular}{|c|c|c|c|c|}
\hline \multirow[t]{2}{*}{ Sources of variation } & \multirow[t]{2}{*}{$\mathrm{DF}$} & \multicolumn{3}{|c|}{ Mean square } \\
\hline & & SAC & $\mathrm{RS} / \mathrm{SAC}$ & SRDC \\
\hline Block & 1 & $0.02 \mathrm{~ns}$ & $0.21 \mathrm{~ns}$ & $0.03 \mathrm{~ns}$ \\
\hline Mother tree & 14 & $2.04 * *$ & $1.11 \mathrm{~ns}$ & $1.59 \mathrm{~ns}$ \\
\hline Error & 14 & 0.29 & 0.96 & 1.28 \\
\hline
\end{tabular}

DF: Degrees of freedom, ns: not significant, **: significant at 0.01 
The average percentage of seedlings with symptoms was $47.9 \%$ (Table 4). It was very variable according to the genotypes of the mother-tree $(\mathrm{G})$; it ranges from $23.6 \%(\mathrm{G} 3)$ and $68.2 \%(\mathrm{G} 15)$. The genotypes more sensitive to cold are: 15, 7, 10, 9, 13 and 6, whereas genotypes 1 and 3 are the most cold tolerant. The mean percentage recovery of seedlings compared to the number of seedlings with symptoms was $53.9 \%$. It oscillates between $36.5 \%(\mathrm{G} 9)$ and $72.8 \%$ (G 6). However, approximately 50\% of seedlings with symptoms (respond to cold) are lost. The percentage loss of seedlings under the influence of cold, after the resumption of seedlings varies between $6.9 \%(\mathrm{G} 3)$ and $35.9 \%(\mathrm{G} 9)$. Although the period from November to February, during the companion of test with shade house, is characterized by lower minimum temperatures (reaching values below 5 ${ }^{\circ}$ C) (Fig. 2B) than those recorded during the same period of the test without shade house (Fig. 2A), there has been no loss of seedlings during the cold period.

Table 4. Average percentage of seedlings affected by cold stress (SAC), recovery seedlings compared to the number of seedlings affected by cold stress (RP / FRP) and seedlings lost as a result of cold stress after the resumption of seedlings (SRDC).

\begin{tabular}{|l|l|l|l|}
\hline Mother tree & SAC & RS / SAC & SRDC \\
\hline 1 & $28.9 \mathrm{fg}$ & 43.1 & 17.3 \\
\hline 2 & $38.6 \mathrm{efg}$ & 52.8 & 18.2 \\
\hline 3 & $\underline{23.6 \mathrm{~g}}$ & 70.9 & $\underline{6.9}$ \\
\hline 4 & $37.0 \mathrm{efg}$ & 43.1 & 21.1 \\
\hline 5 & $41.2 \mathrm{def}$ & 58.3 & 17.4 \\
\hline 6 & $55.6 \mathrm{abcd}$ & $\underline{72.8}$ & 16.7 \\
\hline 7 & $67.3 \mathrm{a}$ & 64.5 & 23.5 \\
\hline 8 & $51.7 \mathrm{abcde}$ & 43.2 & 29.1 \\
\hline 9 & $58.0 \mathrm{abc}$ & $\underline{36.5}$ & $\underline{35.9}$ \\
\hline 10 & $62.4 \mathrm{ab}$ & 50.0 & 31.2 \\
\hline 11 & $38.5 \mathrm{efg}$ & 44.0 & 21.2 \\
\hline 12 & $46.2 \mathrm{bcde}$ & 40.6 & 26.9 \\
\hline 13 & $58.7 \mathrm{abc}$ & 51.7 & 28.3 \\
\hline 14 & $43.3 \mathrm{cdef}$ & 53.6 & 20.0 \\
\hline 15 & $\underline{68.2} \mathrm{a}$ & 57.9 & 29.1 \\
\hline Means & 47.9 & 54.0 & 22.8 \\
\hline
\end{tabular}

Means followed by different letters are significantly different at 0.05

\section{Discussion}

The effect of cold has been a limiting factor on nursery argan (Argania spinosa (L.) Skeels) seedlings production. Indeed, after five months, the cold effect is manifested by yellowing and drying out of the leaves of seedlings from different genotypes. These symptoms are estimates of the response of seedlings to cold [26]. Reduction in seedlings production might be due to reductions in photosynthesis [25]. Cold conditions also induce damage to the root system of seedlings produced in containers, which induces a negative impact on the survival and growth of seedlings [24] [34]. Damage to seedlings under the influence of cold conditions is associated in part to the massive destruction of cells [28] [34] [35] and leaf discoloration (onset of symptoms on leaves) [25] [26] [27] [28] [34] [35]. In this study, the reaction of argan seedlings to cold conditions was significantly different according to genotypes of mother-trees. Some genotypes are more sensitive than others, where the possibility of selection of genotypes resistant to cold stress to improve the production of nursery plants. This variation in seedling survival can be explained by the genetic diversity of plants argan. Numerous studies on several clones or genotypes confirm this diversity to response to different stress [15] [36] [37] [38] [39]. The same results are found in other species [20] [22] [40]. Several plant species have the ability to increase their tolerance in response to low temperatures [19] [22] [41].

The effect of cold conditions did not affect seedlings growing under shade house, and the use of shade structures in nursery seedling production of argan could be necessary as demonstrated by the present study. Indeed, shade houses are used to protect seedlings after germination, the seedlings harden and preconditioned to different environmental stresses [30]. Covered shade house seedlings are not affected by the cold probably because a microclimate was created under shade that stimulates seedling growth. This microclimate can be characterized by temperatures above $10^{\circ} \mathrm{C}$ during cold period.

It is well established that some of the molecular and physiological changes that occur during cold acclimation are important for plant cold tolerance [21] [23]. However, further studies were needed to understand this variability in response to cold stress between different argan genotypes. 

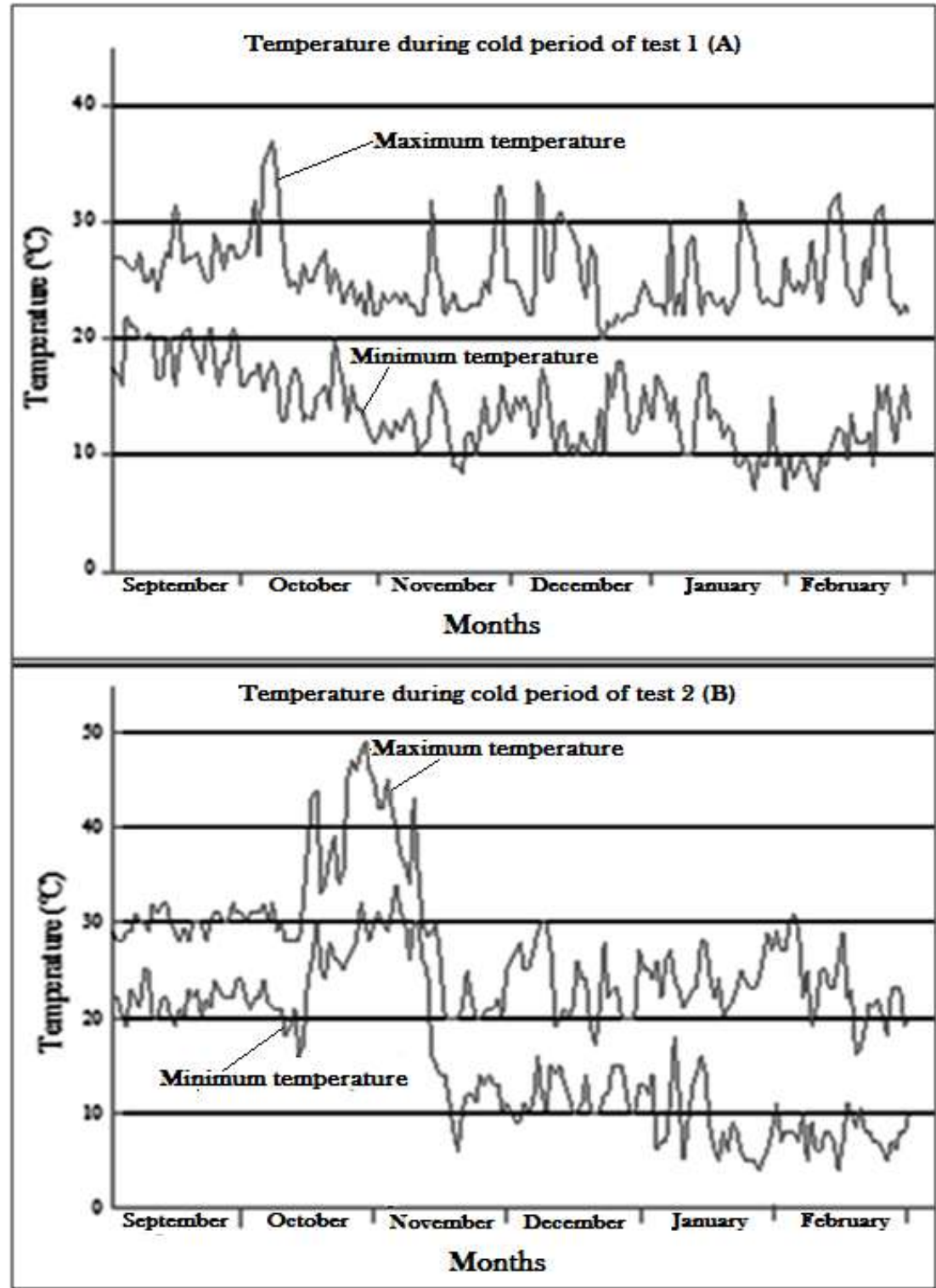

Figure2. Maximum and minimum temperatures during the period September - February of two years (test 1 (A): without shade house) and (test 1(B): with shade house).

\section{Acknowledgements}

We thank the Rectorat of The University Ibn Zohr and the Morocco-Germany co-operative project "Projet de Conservation et de Developpement de I'Arganeraie" (PCDA-GTZ) for financial support.

\section{References}

[1] L. Emberger, Les limites naturelles climatiques de l'arganier, Bulletin de la Société des Sciences Naturelles du Maroc, tome V (1 et 2), 1925, $94-97$.

[2] O. M'hirit, M. Benzyane, F. Benchekroun, S.M. El Youssfi, and M. Bendaanoun, L'arganier une espèce fruitière-forestière à usages multiples, in P. Mardaga (Ed.), Hayen, Sprimont, (Belgique, 1998) 145 p.

[3] L. Emberger, Aperçu général sur la végétation du Maroc, Bulletin de la Société des Sciences Naturelles du Maroc, $1939,40-157$.

[4] A. Ferradous, F. Bani-Aameur, and P. Dupuis, Climat stationel, phénologie et fructification de l'arganier (Argania spinosa (L.) Skeels), Actes de l'institut agronomique et vétérinaire Hassan II, 17, 1996, 51-60.

[5] H.N. Le Houérou, Classification écoclimatique des zones arides (s. 1.) de l'Afrique du Nord, Ecologia Mediterranea 15 (3-4), 1989, 95-144.

[6] A. Zahidi, and F. Bani-Aameur, Argan seedling damping-off under nursery conditions: effetcts of mother - tree genotype, kernel origin and seedling age, Ecologia Mediterranea 24, 1998, 27-32.

[7] P. Boudy, Economie forestière nord-Africaine, in Larose (Ed.), Tome deuxième Monographie et traitement des essences forestières, (Paris (V), 1950), 382-416.

[8] A. Sakai, and W. Larcher, Frost survival of plants, Responses and adaptation to freezing stress, (Berlin: Springer-Verlag, 1987), $321 \mathrm{p}$.

[9] M. Alouani, Régénération de l'arganier (Argania spinosa (L.) Skeels) : protocole de production de plants par semis et par bouturage et réussite de la transplantation, doctoral diss., université Ibn Zohr, Faculté des sciences Agadir (Morocco), 2003. 
[10] M. Chamich, Gestion des conflits liés aux ressources naturelles dans l'arganeraie du souss (Maroc), doctoral diss., université de Toulouse en Etudes rurales, Toulouse, France, 2008.

[11] M. El Yousfi, and F. Benchakroun, La dégradation forestière dans le sud marocain: Exemple de l'arganeraie d'Admine (Souss) entre 1969 et 1986, Ann. Rech. For. Maroc 26, 1992, 43-49.

[12] M. Khay, Traitements sylvicoles et Aménagement: Formation forestière continue, Thème: "L'arganier", Station de recherche forestière, Rabat: 13-17 mars, 1989, 58-64.

[13] M. Mellado, S.O.S. Souss: argan forest destruction in Morocco, Oryx, 23, 1989, 87-93.

[14] J.P. Grime, and B.D. Campbell, Growth rate, habitat productivity, and plant strategy as predictors of stress response, in H.A. Mooney, W.E. Winner, E.J. Pell, E. Chu (Eds.), Response of plants to multiple stress, (Academic Press, Inc., 1991), $143-159$.

[15] M. Alouani, and F. Bani-Aameur, Argan (Argania spinosa (L.) Skeels) seed germination under nursery conditions: Effect of cold storage, gibberellic acid and mother-tree genotype, Annals of Forest Science 61 (2), 2004, 191-194.

[16] F. Bani-Aameur, and M. Alouani, Viabilité et dormance des semences d'arganier (Argania spinosa (L.) Skeels). Ecologia Mediterranea 25 (1), 1999, 75-86.

[17] M. Alouani, and F. Bani-Aameur, Effect of light on germination of Argan (Argania spinosa (L.) Skeels), Acta Bot. Gallica 150 (1), 2003, 59-64.

[18] M. Navarro, Etude fonctionnelle de gènes de facteurs de transcription CBFs impliqués dans la tolérance au froid chez l'eucalyptus, doctoral diss., université de Toulouse, Fance, 2009

[19] T A. Heocharis, C. Clément, and E. Ait Barka, Physiological and molecular changes in plants grown at low temperatures, Review Planta 235, 2012, 1091-1105.

[20] G.C. Boorse, F.W. Ewers, and S.D. Davis, Response of chaparral shrubs to below - freezing temperatures: Acclumation, ecotopes, seedlings VS. Adults, American journal of botany 85 (9), 1998, 1224-1230.

[21] T.H. Hsieh, J.T. Lee, P.T. Yang, L.H. Chiu, Y.Y. Charng, Y.C. Wang, and M.T. Chan, Heterology expression of the Arabidopsis Crepeat/ dehydration response element binding factor 1 gene confers elevated tolerance to chilling and oxidative stresses in transgenic tomato, Plant Physiol. 135, 2004, 1145-1155.

[22] L.A. Wanner, and O. Junttila, Cold-induced freezing tolerance in Arabidopsis, Plant Physiol. 120, 1999, 391-400.

[23] J.H. Zhu, C.H. Dong, and J.K. Zhu, Interplay between cold-responsive gene regulation, metabolism and RNA processing during plant cold acclimation, Curr Opin Plant Biol. 10, 2007, 290-295.

[24] F.J. Bigras, Root cold tolerance of black spruce seedlings: viability tests in relation to survival and regrowth, Tree Physiology $17,1997,311-318$

[25] L.K. Huang, S.C. Wong, I. Terashima, C.B. Osmond, X. Zhand, and D.X. Lin, Chilling injury in mature leaves of rice, 1.Varietal differences in the effects of chilling on canopy photosynthesis under simulated 'dry cold dew wind' conditions experienced in southeast China, Australian Journal of Plant Physiology 16 (4), 1989, 321-337.

[26] Mahajan, A.S. Khehra, and O.S. Singh, Cold tolerance in relation to yield and other characters in maize, International Journal of Tropical Agriculture 10 (1), 1992, 75-78.

[27] G. Oquist, V.M. Hurry, and N.P.A. Huner, The temperature dependence of the redox state of QA and susceptibility of photosynthesis to photoinhibition, Plant Physiology and Biochemistry 31(5), 1993, 683-691.

[28] T.D. Perkins, and G.T. Adams, Rapid freezing induces winter injury symptomatology in red spruce foliage, Tree Physiology 15, 1995, 259-26.

[29] M. Alouani, and F. Bani-Aameur, Limitations actuelles de la production et de la transplantation des plants d'arganier, In F. BaniAameur (Ed.), Colloque International sur les Ressources Végétales, (Faculté des Sciences, Agadir, Maroc, 23 - 25 Avril, 1999), $180-184$.

[30] M.S. Lamhamedi, Y. Ammari, B. Fecteau, J.A. Fortin, and H. Margolis, Problématique des pépinières forestières en Afrique du Nord et stratégies de développement. Cahiers Agricultures 9, 2000, 369-380.

[31] A. Zahidi, and F. Bani-Aameur, Germination des amandes d'arganier (Argania spinosa (L.) Skeels): effet du génotype, de la date de semis et de l'année de récolte. Ann. Rech. For. (Maroc) 30, 1997, 2-16.

[32] P. Dagnelie, Théorie, Méthodes statistiques. Applications Agronomiques, in Presses Agronomiques A.S.B.L. (Ed.), Tome II, (Gembloux : Belgique, 1984), 464p.

[33] D.C. Montgomery, Design and analysis of Experiments, in John Wiley and Sons (Eds.), (New York chichester brisbane toronto Singapore, 1984), $583 \mathrm{p}$.

[34] A.S. Lukatkin, A. Brazaitytè, Č. Bobinas, and P. Duchovskis, Chilling injury in chilling-sensitive plants, Agriculture 99(2), 2012, $111-124$.

[35] E. Ruelland, and A. Zachowski, How plants sense temperature. Environ Exp. Bot. 69, 2010, 225-232

[36] R. Bellefontaine, De la domestication à l'amélioration variétale de l'arganier (Argania spinosa L. Skeels). Sécheresse 21(1), 2010, 42-53.

[37] A. El Mousadik, and R.J. Petit, Chloroplast ADN phylogéographie de l'arganier du Maroc. Molecular Ecology 5, 1996, 547-55.

[38] K. Majourhat, Y. Jabbar, A. Hafidi, and P. Martínez-Gómez, Molecular characterization and genetic relationships among most common identified morphotypes of critically endangered rare Moroccan species Argania spinosa (Sapotaceae) using RAPD and SSR markers. Annals of Forest Science 65(8), 2008, 805. https://hal.archives-ouvertes.fr/hal-00883463/document

[39] R. Nouaïm, R. Chaussod, A. EL Aboudi, C. Schnabel, and J.P. Peltier, L'Arganier : Essai de synthèse des connaissances sur cet arbre. In A.Riedacker, E. Dreyer, C. Pafadnam, H. Joly, G. Bory (Eds.), Physiologie des arbres et arbustes en zones arides et semiarides, (Paris: John Libbey Eurotext, 1993), 373-388.

[40] B. Boedd, F. Lang, A. Keresztes, B. Csapo, J. Kovacs, and E. Paldi, Differences in the etioplast ultrastructure and chlorophyll biosynthesis time course of cold tolerant and cold sensitive maize lines under cold treatment [Zea mays]. Maydica (Italy) 42 (3), 1997, 305-311.

[41] A. Strand, V. Hurry, S. Henkes, N. Huner, P. Gustafsson, P. Gardeström, and M. Stitt, Acclimation of arabidopsis leaves developing at low temperatures. Increased activities of enzymes in the calvin cycle and in the sucrose-biosynthesis pathway. Plant Physiol. 119, 1999, 1387-1397. 